\title{
Measured Decades
}

\section{Haare Williams (Te Aitanga-a-Mahaki, Rongowhakaata, Tuhoe)}

\author{
Pae aArahi - New Zealand Association of Psychotherapists
}

\begin{abstract}
Now and then - a light sneaks in through a crack in the raupō thatch and shines upon a naked child on the floor mat on a dirt floor.
\end{abstract}

\begin{abstract}
Dr (h.c.) Haare Willliams reflects on well-being and ageing through the lens of eight and a half decades of lived experience and learning. He warms us to the theme of the New Zealand Association of Psychotherapists' 2018 Conference, “e tipu ana ... as we grow ...”, as he elucidates the influence on well-being of figural, personal, and world events, of social movements, of treasured relationships, of time - the influences which continue to shape being and well-being.
\end{abstract}

\section{Whakarāpopotonga}

He whaiwhakaaro hauora, whaiwhakaaro koroheketanga tā Haare Wiremu mai i ngā karu o tētahi kua waru me te haurua ngahurutanga te koiora wheako whaiaro me te whakaemi mātauranga. Ko tāna he whakamahana i a tātau ki te kaupapa o te Wānanga o te tau 2018 a te Rōpū Kaiwhakaora Hinengaro o Aotearoa, “e tipu ana ...”, i a ia e whakamārama ana i te pānga ki te oranga ā-karetao, ā-whaiaro, kaupapa ā-ao, ngā whakanekenekehanga hāpori, ngā whanaungatanga puiaki, te haere o te wā - ngā whakaaweawe e hanga tonu nei i te koiora me te hau ora.

Keywords: Māori; wairua; age; time; growing; life

For a start, I intensely dislike phrases like "growing old". Let's banish the word "retirement". So, I'll draw upon a personal perspective.

I was brought up in remote New Zealand on the sheltered shores of the Ohiwa Harbour, the "son" of grans Rimaha and Wairemana. Speaking English only kicked in at eight when I started school. For twelve years I was their cherished "son". We lived with the virtues of Land, Harbour and Streams, and Bush. And listening. My wellness was a cohabitation with marae, the arts of marae and storytelling, Ringatu, followed by schooling. I watched my grans, Wairemana and Rimaha, age, grow frail before my eyes. But they never grew old. I invite you to walk with me along the decades of my journey.

Williams, H. (2018). Measured decades. Ata: Journal of Psychotherapy Aotearoa New Zealand, 22(1), 11-21. https:// doi.org/10.9791/ajpanz.2018.02 


\section{4, Born in Te Karaka, Gisborne to Te Wehinga Williams and Ereti Brown}

Born under a cabbage tree (I'm told).

Gifted from Te Aitanga-a-Mahaki to Tuhoe tribal kin of Ohiwa.

As Puukenga, a strategy for learning through apprenticeship where listening, talking and doing were the key learning principles.

Life in Ohiwa included vespers, evening amine, Songs of David and Solomon.

Besotted by Wairemana, the intrinsic love of grandparents.

By feminine stealth she cared for her moko - he cared for her.

Exposed to best practices for co-existing with the natural world while absorbing a diversity of matauranga.

They thumbed their noses to adversity and poverty, went on and adapted things to suit, he lived with it and by it. They practiced their religious and devout belief in the land, harbour and bush to take care of them. They lived a frugal and balanced lifestyle.

Killed a "Maori Bug".

He felt the whips, scars and scorns of their Tuhoe losses through the power of their storytelling.

Labour had evolved into a party of social liberalism, with a policy platform that called for the state to provide reforms such as free education, a salaried medical service, a free public hospital system, adequate standards of housing, the family benefit, a basic minimum wage and full employment. Labour set up the first social security system in the world.

Then, the Depression: the unemployed were put into work.

In 1941 my grans received the "Old Age Pension” (a decade after Pakeha).

Manuel Hape Thompson Taipapanui Wells Aramoana.

Free milk in schools, and red apples too - I was called up as "the milk monitor."

From 1935 to 1939, then Education Minister Peter Fraser planned reforms with education as its cornerstone. “... every person, whatever his level of academic ability, whether he is rich or poor, whether he live in town or country, has a right, as a citizen, to a free education of the kind for which he is best fitted and to the fullest extent of his powers" (Beeby, 1992, p. 124).

War was looming in Europe.

For many the idea of ageing is both daunting and challenging, sometimes appalling, as we face growing incapacity. It is the challenge that is the blessing of life. I know that karakia helps me keep myself and my wairua in balance, and that has allowed me to age in a meaningful way. God's work tumbles out new and endless uncertainties for us to find solutions to.

\section{4, School and War}

In 1944 I settled into Karaka at Ohiwa; marginal land made malleable for growing food. Read in English to Wairemana; she regaled me with stories of Tuhoe.

At eight, started school at Kutarere; called “The Kutu Kids” ... or “The Maori Bugs”. 
I was fearful of speaking Māori at school - te reo stopped at the school gate. Te reo remained on the marae and in conversation, natural and free, the Bible ... and the prophecies of Te Kooti.

Children of the entire community belonged. I was nicknamed "Lahi" in place of "Harry". I collected bad dreams, put them into a bag, tightened the drawstring and sequestered them out into the harbour and ocean.

This was kāinga. Sky above, land below, harbour in front, the bush behind, the streams and springs to one side and the cultivations to the other; beyond the horizon, the Guardians, and here is kaiinga: home for the heart, mind, spirit and body.

Wairemana - "The Michelangelo, the Mozart, the Shakespeare of gastronomy ... smell the boutique of fried herrings like vintage wine".

WWII, I watched as young men were recruited and sent away to Europe embroiled in war. The Māori Battalion.

Roosevelt, Churchill, Stalin. (Fraser was Prime Minister in New Zealand).

Britain, France, Australia, Canada, New Zealand, India, the Soviet Union, China and USA - McArthur, Paton, Eisenhower, Montgomerie, Freyburg, Dittmer, Henare, Bennett, Awatere.

26 March 1943, 2nd Lieutenant Ngarimu VC, Tebaga Gap.

In 1946, I watched in awe as a Lancaster bomber flew past above the school - a "thank you" from Churchill.

Ringatu, they expressed their religious and devout beliefs each morning at $4 \mathrm{am}$, reverence for all nature. Wairemana's prophecy: “... you can be anything”.

1949, I started at Opotiki District High School - the school-bus service allowed rural (Māori) kids access to secondary schooling, taking me 40 miles from home.

Māori culture, like Matariki, offers another way to look at ageing (quite different from "getting old"). There's more than one way. I have watched a diversity of peoples "grow old" and struggle with the very idea, hence my plea, "Banish the word, old".

\section{4, Years of Finding Out}

Met my parents and family for the first time at Waiotahi Beach.

Dux of class, became a prefect, tennis and athletics championships, member of First XV. 29 January 1954, 6 a.m. Kutarere Shop farewell. Entered Ardmore Teachers' College after a second year in fifth form (School Certificate).

Realisation of the dream to be a teacher - an image in the pools, the mudflats, the old wharf, scow at Ohiwa.

(Graduated as a teacher with Trained Teachers Certificate - went back to Kutarere, "I am now a teacher. Thank you").

1956, teaching at Maungatapu - the transformative power of being “Teacher".

Met and married Margaret Haua of Ngaiterangi.

Songs: "Tom Dooley”, "Long Tall Sally”, "Why do fools fall in love”.

Howard Morrison Quartet.

The dream car to look at, a Ford Zephyr Six. 
Time of "the juvenile delinquents", Elvis Presley, the Beatles, Bill Haley and the Comets, "Rock around the clock" ...

Ruia Morrison at Wimbledon, ranked ninth in the world.

Sputnik; Soviets sent into orbit around the planet Earth.

My son Hemi was born in Tauranga.

Learned something about sentient mountains, rivers, stars, whales and birds through re-telling stories ... that embodied wairua.

Young, naïve and idealistic champion of the underdog driven by passions and a prevailing philosophy of timelessness.

Of course, at twenty, I was never going to get "old”. I want to share the joy of my life's decades. When I use the word "ageing", I mean becoming more of a person as I journey through. I grew up around the marae at hui, in a devout Ringatu setting, being positioned between people distilled in the knowledge and wisdom of the tribe through layered stories tracing back to Creation in whakapapa. I sat with elders, time improved them with the depth of matauranga and richness. My grans gave me their most precious taonga - TIME.

\section{4, Teaching, Learning and Growing}

Principal at Matauri Bay School - learnt the meaning and heart of teaching, growing and living.

Enriched and grew as a teacher - hard work, discipline and reverence. Learned to succeed and grow with humility.

Keri was born in Tauranga.

Sole teacher at Te Aputa School (Turangi), Lake Taupo.

(1962) Waitangi Day - visit with children, met George Brown, Sir Turi Carroll and

Prime Minister Keith Holyoake. PM was amused when children bowed and addressed him as "Your majesty".

"Lawrence of Arabia” movie, featuring Peter O'Toole.

(1963) Mark born in Whangaroa Hospital in Kaeo.

Set up a thriving and popular tennis club at the school.

Met J. B. Smith, the great All Black.

James Henare (later Sir) and Graham Latimer (later Sir) visited school in support of Māori teachers.

Kennedy assassinated.

Cold War: ideological struggle between the Western powers and the Soviet Union.

The Berlin Wall was a guarded concrete barrier that physically and ideologically divided Berlin from 1961 to 1989.

(1967) wife Margaret attended Auckland Teachers' College in Epsom.

(1960) Selected to attend Youngs Leaders Conference at Turangawaewae Marae - led by Matiu Te Hau, Maharaia Winiata and Pei Jones, John Waititi, Peta Awatere, Bishop Panapa ...

Norman Kirk appeared on the political horizon with a strong stance against racism.

Of course, I knew everything. 
Each decade has incrementally shaped me, each adding one step to the next. Time moves, my growth has expanded, I became a richer, more interesting person. In that way, the very purpose in life is to age and become what I truly am. Human beings age in similar ways. Ageing has given me something ... something transformational inside: where the soul blossoms. Wairua. I believe that wairua is what remains after medicine and psychology have tired and analysed us. For me, this is a time of a profound sense of self, far beyond what is known as ego, that connects with others. Like the word "soul", wairua is not a technical or scientific term but an ancient one, rooted in the idea of breathing, responding, living - and being. My early career was all about me: gaining prestige, making a living, feeling successful.

\section{4, The Age of Political Change}

(1972) Norman Kirk was Prime Minister and lead an activist government - two warships sent to Mururoa. (Kirk died in 1974).

(1974) Established NZ Artists and Writers Association in Te Kaha.

British Empire Games in Christchurch.

Start of the Papakura Marae.

Stopped a Springbok tour going ahead. No visas to South African rugby team.

Give our young people education that will allow them to conquer the world. That's the most precious thing we can give our children.

Richard Nixon impeached.

(1975) Matiu Rata created the Treaty of Waitangi Tribunal.

Strident voices of protest - political activism calling for the Treaty to be honoured.

I left teachers' college, trained as a journalist at NZBC - covering issues was like being on a war-front.

Whina Cooper led a hikoi to the steps of Parliament. One of the defining moments of the decade came with the Māori land march, significant in politicising Māori land issues.

Fighting for the New Zealand government to save your country from the evils of communism and then fighting the government to save your land.

Robert Muldoon was the most divisive Prime Minister ever; “Think Big” projects.

Throughout the 1970s the press and talk-back radio had open field days about barbaric tribalism, Māori savagery, and cannibalism by the redneck rump of New Zealand (nothing could controvert that impression at the time).

Britain began its headlong decline as a super-nation; the colonial attachments between New Zealand and the United Kingdom were to be irrevocably altered when Britain entered the European Economic Community. Younger generations did not value the imperial connections to Britain in the same way as those who fought in the two world wars.

Early 70 s saw the appearance of unemployment for the first time since the Depression. In 1976 the USS Truxton, a warship, and in 1978 the USS Pintado, a nuclear submarine, were stopped mid-Waitemata.

The dawn raids and stereotypes that were paraded in the media.

Recurring themes in the 1970s: loss of important resources, along with language loss, 


\section{Measured Decades}

and the loss of cultural integrity.

Planned visits to marae by teachers' college students (Maungatapu, Otiria, Wanganui, Otamatea and Bethlehem).

"Eminent Researcher" with the Waitangi Tribunal.

(1977) Appointed to Waikato University Research Centre -Ritchie, Rangihau and Mahuta - examining Treaty breaches.

The buzz word, "Biculturalism". It became a term that is understood in New Zealand to mean the relationship between tangata whenua and tangata Tiriti.

(1978) Research Fellow at Waikato University - gave my first lecture on the rising of Puanga (Rigel) and Matariki (Pleiades) heralding the new year in mid-winter.

Bastion Point - unoccupied land at the centre of New Zealand's largest city. Robert Muldoon was scathing of the protestors and the rights of Māori.

(1979) Son Hemi graduated from medical school, Auckland University.

When I was 40 I didn't know I was young; I didn't think I'd ever get old. When I was 50 I thought that people over 60 were "old". When I was 60 I wanted to be 40 again. I can just be me now. I have learned to manage ageing through engagement and finding a purpose and living it. This is to find spiritual meaning.

\section{4, A Political Watershed}

Aged 50.

First time since mid- $19^{\text {th }}$ century that people who suppressed the Mãoriness expressed it assertively.

Two terms as City Councillor.

(1983) Wattie's Book Award Judge.

Held first solo art exhibition in Auckland.

Sir Hugh Kawharu, Ranginui Walker and Pat Hohepa, along with a generation of researchers, teachers, lawyers, and actors provided Auckland with the most powerful line-up of scholars and something of a high point in Māori scholarship and dramatic/ cinematic activity.

(1981) Springboks tour goes ahead.

David Lange's government banned nuclear warships from anchoring in New Zealand waters. Lange symbolised a moral, independent, powerful identity for New Zealand; a small nation. Aotearoa New Zealand has gained a unique place in global politics as a small nation prepared to take a nuclear-free stance in the face of great power pressure.

(1986) Pope John Paul II visits New Zealand.

(1987) Aotearoa Radio opens in Auckland with a new sound for New Zealanders. Their practice reflects Māori cultural values with the aim of revitalising Māori language, knowledge and culture.

Kohanga reo for Māori, which was to become one of the defining programmes of the 1980 . By the end of the decade more than 500 had sprung up around the country Sir James Henare, Dame Te Atairangikaahu, Puketapu, and other kaumatua supported. 
Te Wānanga o Aotearoa (as well as 26 other tertiary institutions) faced with multiple interventions from New Zealand Qualifications Authority, including enrolment bans. "A prodigy university", Jim Mather told us.

(1984) Hikoi to Waitangi from Turangawaewae - Wetere, Bennett, Tauroa Hiwi and Pat Williams organised the hui.

(1984) Treaty of Waitangi legislation back-dated to 1840 - opened another Pandora's box.

Worked with Tauranga Moana claims - preparing claimants with claims: Judea, Tamapahore, Bethlehem, Matapihi (Pahauwera, Thames, Otamatea).

(1989) Development of Māori Broadcasting as General Manager of Aotearoa Radio - a gathering of a galaxy of stars - Morrison, Lagaia, Maniapoto, Dalvanius Prime, Hinewehi Mohi, Libby Hakaraia, Ropata ...

(1986) - engaged with New Zealand Association of Psychotherapists.

Each decade shaped me and left me ageing differently.

Our world is failing to deal with a widespread obsession (and depression) with youthfulness, acquisition of power and beauty. Society fears getting old and retirement, and needs to find ways to calm that anxiety before it blooms into a real dust storm. At 60 I didn't know what ageing was. At 60 I felt ancient and wished I had been born 20 years younger. I didn't want to live beyond 70 .

\section{4, Waitangi Political Activism}

(1990) Commonwealth Games held in Auckland, tall ships and waka in Gisborne (5 waka), Auckland (7 waka) and Waitangi (21 waka).

New Zealand Commission. I was handed the task of building twenty-one waka to take safely to Waitangi and back.

New Zealand's Sesquicentennial, 150 years since signing of Treaty - twenty-one waka at Waitangi with five tall ships and HMNZS Canterbury in the presence of Her Majesty Queen Elizabeth II, the "spirit of New Zealand" rekindled.

Visit to London with waka. Tahere Tikitiki of Tainui appeared on Royal Regatta at Henley-on-Thames, Flower Show at Sandringham and Buckingham Palace in London. Hit song, "Welcome to our Word" by John Grennell. Featured in Toyota ad featuring Stevie Askin and Peewee Tuapawa at Tolaga Bay.

Māori were to extract important concessions from the Labour and National governments from the mid-1990s.

(1994) Aged 6o. Unitec Senior Management Team Pae Arahi position created.

Dean of Faculty and two years later the Unitec Senior Management Team.

(1995) The Crown signed a Deed of Settlement with Waikato-Tainui that year. This included a formal apology for the actions taken in the wars of the 1860 s and their legacy as

... wrongful and totally unjustified ... Waikato-Tainui, far from being in rebellion, were in fact defending hearth and home ... The Waikato war and the confiscations that followed caused devastation ... The 
people were dispersed, and there was widespread suffering, distress and deprivation ... The land of their ancestors had been taken from them at the stroke of a pen. (Ministry for Culture and Heritage, 2014, para.1)

By the end of the 1990 s iwi and iwi organisations offered a wide range of cultural, employment, education and health services funded by both the state and the capital available from Treaty settlements. None of these were beyond reproach.

South Seas Film and Television School School set up Rongo - Mãori content in film and TV.

I watched and marched, joined protests and saw a nation go through the birth-pains of a rebirth. This was a turning point, a moment of truth when I really began to think about ageing and my role. I didn't understand it nor was I able to reflect on what it was doing to me. It was just a bit scary. Hey, it's okay to be comforted and cheered up by positive experiences in nature and being among friendly and positive people.

\section{4, Aged 70}

Unitec marae development and Te Noho Kotahitanga - Treaty responsiveness.

Māori Television founded.

(2006) Remuera address.

(2007) With Manukau City Council, advisor to Sir Barry Curtis (and later Len Brown and Phil Goff).

(2008) Moved into Papakura - home.

Chair of Lotteries Board Heritage Committee; Chair of ProMa funding for general practitioners to improve Māori health outcomes.

(2009) Barack Obama elected President.

(2012) Earthquakes in Christchurch.

Arena becomes AUSA President.

(December 6, 2013) Nelson Mandela charmed New Zealanders with his mana, smile and messages of thanks during his only visit here as President of South Africa.

At 70, I noticed people in their early 5os or even 40 s complaining about getting old. It's only by stepping away from that illusion that we may be able to enjoy ageing - especially if we can see signs that life has taught us something, and not only are we getting older, we're getting richer.

When people think of staying youthful as they age, they often think physically by getting facelifts, but not personality lifts. They try to look young without being young. Wairua is still closeted in a dark corner. For some, their physical condition often mirrors their emotional inside. If the spirit of youth is strong and wairua is strong, you may start to see and feel it more strongly in your body as well.

From D. H. Lawrence (1994, p. 417), “... They would distil the essential oil out of every experience And like the hazel nuts in autumn, at last Be sweet and sound. And the young among the old Would be as in the hazel woods of September nutting, Gathering nuts of ripe experience". 
In later years, I've tried not to succumb to doubt or despondency. Resignation is one of the unhappiest solutions to the challenge. Some have got old without having aged, and their lives echo with unfulfilled promise and regrets.

Resignation is the act of shutting down, and perhaps being so discouraged instead of fighting the longer fight. Give up and the spirit gives up. They have lost faith in themselves and their talents, and forgotten to take on new risks and try new and endless uncertainties.

\section{4, "Rough Winds do Shake the Darling Buds of May ..."}

Aged So.

Senior Vice President of the Labour Party. Worked with Labour leaders - Shearer, Cunliffe, Mahuta and Jones.

Arena stood in pure blue electorate of Hunua and took $35 \%$ of votes.

(2015) Arena admitted to The Bar in Auckland High Court.

Waitangi Tribunal: Story is transformed into a new story, no longer about powerlessness ... no longer about shame and humiliation, it becomes a new story about human dignity, mana and virtue. The reconstruction of our story is a key principle of trauma healing and recovery to find spiritual meaning.

Arena graduated with degrees in Law and International Commerce.

Institutions of the state: parliament, law, education and the media ... their dream, to lay the foundations for a more equal democracy.

(2015) Named Companion of Auckland Museum.

(2016) General Election, 18 Māori in parliament.

(2017) Membership of New Zealand Institute of Architects.

Member of the Literary Society.

Arena spent eleven months in total immersion te reo. In November, Te Makahi Robert Hardie (mokopuna) was born.

Received an honorary doctorate in Education and named a Member of the New Zealand Order of Merit.

2014, at age So - our beautiful nation is prophetic, intuitive, and at its roots is a deep spirituality which springs essentially from our history and cultures. In peace terms, we're closer now than perhaps the 1860 .

Today, 2018, I look to young leaders emerging, Arena and her cohorts, Māori and Pakeha and other races fluent in both languages, interested in politics, economics and management.

Our society can be enriched by stories of patupaearehe or taniwha as much as stories of dragons and leprechauns.

New Zealand can lead to a radical contribution to world missions. Redemption is a huge issue that faces all of us globally. Looking back over the decades, I see that one of the most important things that takes place in the hearts of the offended is the release from unresolved grief. We have a long way to go, but the first step is to be applauded.

"Rough winds do shake the darling buds of May ... and summer's lease has all too short a date" (Shakespeare, 1608/2004, p.39).

Favourite people: Rukupo Ngata Buck Te Puea Parker Morrison Kirk Rata Cooper 
Rickard Jacksons Ritchie/Rangihau Wetere Walker Latimer Te Kanawa Smith JB Henare Winiata Reeves Kawharu Tuwhare Harawira Vercoe Shelford Lincoln Ghandi Mandela Kennedy Pope John Kirk

Favourite places: Ohiwa, Matauri Bay, Ardmore

Favourite tipuna: Te Kooti

Favourite food: fried bread and herrings

Favourite drink: water

Favourite colour: the emerald-blue of Ohiwa

Favourite word: Serendipity (serepidity)

Best movies: Lawrence Olivier's “Hamlet” (Lawrence of Arabia)

Best songs: "Rivers of Babylon", "Sounds of silence"

Favourite quote: "I'm a doctor and well trained for my job. My dad is now a doctor too because he is educated".

Ageing tumbles out new and endless contradictions and imperfections - for us to find solutions. Ageing requires courage. It's an active engagement with wairua. Say yes to life's many invitations. Take on God's offer of uncertainties. Don't make excuses. Don't hide. Accept sadness but appreciate its joys.

So let's be the exact age we are. Reflection has helped me deal with change. It makes for more thoughtful and deeper states of being. And that means ageing with grace. Reflection means I can think about experiences that develop the internal and external parts of me. With reflection, I can draw closer to my emotions, my kids, whānau and all Nature. I am more than a cardboard cut-out without wairua. Through reflection, I can accept, learn and understand that all my mistakes and stuff-ups were part of the puzzle that made me the person I am. Illness can also heal. My grans, Wairemana and Rimaha, turned poverty and alienation into a strength. Their poverty and poorness became my richness. Their losses of Tuhoe lands became their strength. Being alienated forced them to rebuild. They were good people who became better people with age. For me they never grew old. They aged with mana.

Sometimes standing on Maungakiekie or stepping into whare tipuna, a few lines of "Whakaaria Mai" is all I need. I get another and other lifts when I am with my grandkids, around young people thirsting for the stories of their tipuna and why they too are heroes. Rangatahi respond well when I confess to mistakes and my set-backs.

Karakia is part of life that brings people together in a meeting of minds and spirit. All prayers acknowledge the presence of God and makes a connection with the realm of the spirit, and thus enables me to play my part in Creation. Karakia has enriched every part of my life.

The American songwriter Edgar Yipsel "Yip" Harburg, who died in 1981, gave us this taonga, "... somewhere over the rainbow bluebirds fly, Birds fly over the rainbow, Why then, oh, why can't I?” (Arlen \& Harburg, 1939). That's a maxim or a truth for staying young.

Knowing how to age isn't just about getting older, it is a taonga that's meant to ripen character and personality.

I had a dream as a kid, to walk up the tracks that clung to the hillside, cross the Ohiwa mad-flats and keep walking. I walked and history walked with me. Nan Wairemana cried without a sound. As I walked I remembered sitting in the early chill.... she starts a fire in the 
cooking pit. When the flames take hold, she fills a billy with water from the spring under the gnarled ngaio tree. We chat idly awhile in hushed voices of small inconsequential things, one breath warming the other. Happy moments, moments never to be forgotten. Her boy smiles, "E ma, I love you." I knew she wanted me to wave when I walked over the ridge. That was the last time he saw her.

And now, the light sneaks back out of the crack in the raupō, smiles awhile - and tumbles out new and endless contradictions - to be solved.

\section{References}

Arlen, H. (Composer), \& Harburg, E. Y. (Lyricist). (1939). Over the rainbow. On The Wizard of Oz [78rpm vinyl]. New York, NY: Decca Records USA.

Beeby, C. (1992). The biography of an idea. Wellington, New Zealand: New Zealand Council for Educational Research.

Lawrence, D. H. (1994). Courage. The complete poems of D. H. Lawrence. Ware, England: Wordsworth Editions.

Ministry for Culture and Heritage. (2014). The Waikato-Tainui claim. Retrieved from https:// nzhistory.govt.nz/politics/treaty/the-treaty-in-practice/waikato-tainui

Shakespeare, W. (2004). Sonnet 18. In B. A. Mowat \& P. Werstine (Eds.), Shakespeare's Sonnets. New York, NY: Washington Square Press. (Original work published 1608)

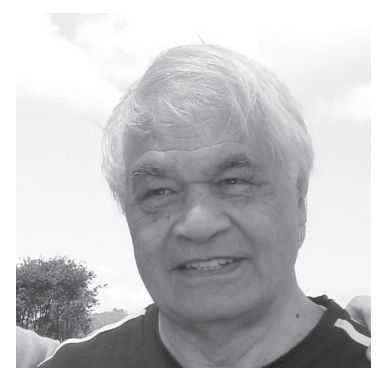

Dr (h.c.) Haare Mahanga Te Wehinga Williams was born in $\mathrm{Te}$ Karaka in the rural heart of Te Aitanga-a-Mahaki. At two months he became a living gift to his Tuhoe grandparents. He was raised in a whare raupō at Karaka, located between Ohiwa and Opotiki, not speaking English until schooling started at age eight. Immersed in the life and practices of another generation, Haare's grans gardened, fished and preserved food according to a Māori calendar. They exposed him to best practices for coexisting with the natural world while he absorbed a diversity of matauranga (insights). Haare's grandparents' mode of gardening applied the knowledge of Māori, his physical nourishment was matched with the spiritual substance he received through Te Kooti's scriptural-based waiata such as The Songs of David and Solomon. Ringatu writings were inspirational texts which grew into his love of language, poetry and narrative. His formative years exposed him to the regularity in which Mãori history was told, which explains a Mãori view of New Zealand history according to the values, constraints and changes he has seen. As a writer, his current project, Puakina - Songs of the Living Word, comes from ideas that have engaged his imagination since childhood. In his art he paints, he writes and he narrates a personal experience of faith that is both forward-looking and reflective. His visual language gives new significance to values from his upbringing, his spiritual beliefs and personal experiences. Contact details: haare.williams@gmail.com. 